Dedicated to Prof. Qamrul Hasan Ansari on the occasion of his $60^{\text {th }}$ anniversary

\title{
Coincidence point theorems for KC-contraction mappings in $J S$-metric spaces endowed with a directed graph
}

\section{WAtchareepan Atiponrat ${ }^{1,2}$, Supreedee DANGSKul ${ }^{1,2}$ and ANCHAlee KHEMPHET $^{1,2}$}

\section{ABSTRACT.}

We introduce the class of $K C$-contraction mappings and prove some coincidence point theorems for these contractions in $J S$-metric spaces endowed with a directed graph. An illustrative example as well as an application to integral equations are also given in order to support our main theoretical results.

Acknowledgment. The authors would like to thank Chiang Mai University for financial support.

\section{REFERENCES}

[1] Ansari, Q. H., Extension of generalized variational-like inequalities, Southeast Asian Bull. Math., 23 (1999), No. $1,1-8$

[2] Ansari, Q. H., Idzik, A. and Yao, J., Coincidence and fixed point theorems with applications (Dedicated to Juliusz Schauder, 1899-1943), Topol. Methods Nonlinear Anal., 15 (2000), No. 1, 191-202

[3] Ansari, Q. H., Rezaie, M. and Zafarani, J., Generalized vector variational-like inequalities and vector optimization, J. Global Optim., 53 (2012), No. 2, 271-284

[4] Ansari, Q. H. and Yao, J., An existence result for the generalized vector equilibrium problem, Appl. Math. Lett., 12 (1999), No. 8, 53-56

[5] Ahmad, J., Hussain, N., Azam, A. and Arshad, M., Common fixed point results in complex valued metric space with applications to system of integral equations, J. Nonlinear Convex Anal., 16 (2015), No. 5, 855-871

[6] Berinde, V., Iterative approximation of fixed points, Lecture Notes in Mathematics 2nd Edition, Springer, Berlin (2007)

[7] ElKouch, Y. and Marhrani, E. M., On some fixed point theorems in generalized metric spaces, Fixed Point Theory Appl., 23 (2017), 17 pp.

[8] Hussain, N., Azam A., Ahmad, J. and Arshad, M., Common fixed point results in complex valued metric spaces with application to integral equations, Filomat, 28 (2014), No. 7, 1363-1380

[9] Jleli, M. and Samet, B., A generalized metric space and related fixed point theorems, Fixed Point Theory Appl., 61 (2015), 14 pp.

[10] Jachymski, J., The contraction principle for mappings on a metric space with a graph, Proc. Am. Math. Soc., 136 (2008), 1359-1373

[11] Roshan, J. R., Parvaneh, V. and Altun, I., Some coincidence point results in ordered b-metric spaces and applications in a system of integral equations, Appl. Math. Comput., 226 (2014), 725-737

[12] Saluja, G. S. and Tripathi, B. P., Some common fixed point theorems of generalized contractive mappings in cone metric spaces, Funct. Anal. Approx. Comput., 5 (2013), No. 1, 33-41

[13] $\mathrm{Wu}, \mathrm{X}$. and Zhao, L., Fixed point theorems for generalized $\alpha-\psi$ type contractive mappings in $b$-metric spaces and applications, J. Math. Computer Sci., 18 (2018), 49-62

Received: 07.03.2019; In revised form: 25.06.2019; Accepted: 02.08.2019

2010 Mathematics Subject Classification. 47H04, 47H10, 54H25.

Key words and phrases. fixed points, coincidence points, common fixed points, JS-metric spaces.

Corresponding author: Anchalee Khemphet; anchalee.k@cmu.ac.th 
${ }^{1}$ Department of Mathematics

Research Center in Mathematics and Applied Mathematics

FACULTY OF SCIENCE

CHIANG MAI UNIVERSITY

CHIANG MAI 50200, THAILAND

E-mail address: watchareepan.a@cmu.ac.th, supreedee.dangskul@cmu.ac.th, anchalee.k@cmu.ac.th

${ }^{2}$ Department of Mathematics

DATA SCIENCE RESEARCH CENTER

FACULTY OF SCIENCE

CHIANG MAI UNIVERSITY

ChIANG MaI, THAILAND, 50200

E-mail address: watchareepan.a@cmu.ac.th, supreedee.dangskul@cmu.ac.th, anchalee.kecmu.ac.th 